\title{
Orchids From Five Districts in Fakfak Regency, West Papua: Diversity and Distribution
}

(Studi Keragaman dan Persebaran Anggrek (Orchidaceae) pada Lima Distrik di Kabupaten Fakfak, Papua Barat)

\section{Reza Saputra}

West Papua Natural Resources Conservation Agency, Ministry of Environment and Forestry, Indonesia. Jalan Klamono KM 16, Sorong, West Papua, Indonesia. Postal Code 98417. Phone +62951 321986

\begin{tabular}{|c|c|}
\hline Article info: & ABSTRACT \\
\hline $\begin{array}{l}\text { Keywords: } \\
\text { Fakfak Regency, } \\
\text { Orchids Diversity, } \\
\text { West Papua }\end{array}$ & $\begin{array}{l}\text { A study of the diversity and distribution of orchids has been conducted in five districts } \\
\text { in Fakfak Regency, i.e. Kokas, Fakfak Tengah, Fakfak, Wartutin, and Karas. This study } \\
\text { was conducted based on current condition that research on orchid inventory has never } \\
\text { been carried out in Fakfak Regency. Therefore, there is lack information and report } \\
\text { related to the data of orchids collection from this regency. The objective of the research }\end{array}$ \\
\hline $\begin{array}{l}\text { Article history: } \\
\text { Received: } \\
\text { 8 October 2020; } \\
\text { Revised: } \\
2 \text { December } 2020 ; \\
\text { Accepted: } \\
\text { 10 December } 2020\end{array}$ & $\begin{array}{l}\text { was to provide a preliminary note on the diversity and distribution of orchids in the } \\
\text { Fakfak Regency. The study was carried out using the Visual Encounter Survey and the } \\
\text { Purposive Exploration method. The result determined } 67 \text { collection numbers consisting } \\
\text { of } 49 \text { epiphytic orchids, } 16 \text { terrestrial orchids, and two holomycotrophic orchids } \\
\text { classified into } 33 \text { genera and } 67 \text { species. Fakfak Tengah District has the most diverse } \\
\text { orchids species compared to other districts, viz. } 37 \text { species. }\end{array}$ \\
\hline
\end{tabular}

\section{Introduction}

New Guinea is the richest island of flora in the world, with 13,634 described plant species (Cámara-Leret et al., 2020). More than half of them are endemic to this island. The richest and most endemic vascular plants in New Guinea is Orchidaceae (Vollering, Schuiteman, de Vogel, van Vugt, \& Raes, 2016). In June 2020, New Guinea has 2,856 species of orchids (Cámara-Leret et al., 2020). The latest publication has announced the new finding of orchid species in West Papua namely Dendrobium sagin Saputra \& Schuit (Saputra, Mustaqim, Metusala, \& Schuiteman, 2020), summing the total number of 2,857 wild orchids species in the Papuasia Region. Among those number, 2,465 are endemic to Papua, with the endemicity levels up to $86.27 \%$ (Cámara-Leret et al., 2020).
Most parts of New Guinea still has low orchids collecting density (Juswara, Schuiteman, \& Droissart, 2016). Based on Vollering et al. (2016), orchids collection in the Western New Guinea (Papua and West Papua Province, Indonesia) is still low, compared to the Eastern New Guinea (Papua New Guinea). The statement was also supported by de Vogel (personal communication, 2018), who stated that there are still many Papuasian orchids species that are not yet known, especially in the western New Guinea. One of the lowest orchids collection density in Indonesian New Guinea is Fakfak Regency, West Papua Province. The orchids diversity in this regency has never been explored by the Indonesian Institute of Science (LIPI) or Royal Botanic Garden (RBG) Kew, only from some individual orchids enthusiasts or researchers. Due to limited research on

Editor: Dr. Henti Hendalastuti Rachmat

Author correspondence: Reza Saputra* (E-mail: reza.saputraa21@gmail.com)

Author contribution: RS: Design research methods, conduct inventory research/exploration in the field, identify specimens, analyze data, make the manuscript. 
orchid diversity that has been conducted in Fakfak Regency, it is suspected there are still many unknown orchid species in this area.

Fakfak Regency is geographically located between $131^{\circ} 53^{\prime} 03$ "E - $133^{\circ}$ 29'19" E and 02 ${ }^{\circ} 30 ' 58$ "S - $03^{\circ} 57^{\prime} 51^{\prime \prime} \mathrm{S}$ with an area of $14,320 \mathrm{~km} 2$, which is divided into 17 districts (Badan Pusat Statistik Kabupaten Fakfak, 2014). Based on the Schmidt and Ferguson climate types, Fakfak Regency has type A climate with rainfall of more than $100 \mathrm{~mm} / \mathrm{month}$, which has wet months $>9$ and dry months $<2$ (Pemerintah Kabupaten Fakfak, 2011). The development in Fakfak Regency is intensively carried out, which will more or less result in forest degradation and decline of the orchids population. Therefore, research related to the inventory of orchid diversity in the Fakfak Regency needs to be done before further degradation of the orchid population occurs in this area. This research's objective is to provide a preliminary note on the diversity and distribution of orchids in the Fakfak Regency.

\section{Methodology}

2.1. Time and Location of Research

Research on orchid diversity and distribution was carried out in several districts in Fakfak Regency, including Fakfak (Fakfak Mountain Nature Reserve at 250-1,000 m asl), Kokas (Ugar Village Forest at 1-150 m asl), Fakfak Tengah (Air Besar Forest at 1-400 m asl and Sekartamen Forest at 1-150 m asl), Wartutin (Hanatpona Forest at 1-100 m asl), and Karas (Maas Village Forest at 1$50 \mathrm{~m}$ asl), West Papua (Figure 1). The research was conducted on February 15 April 22, 2016, and continued on April 47, 2019.

\subsection{Material and Tools}

The material used in this research were alcohol $70 \%$, herbarium paper, specimen's label, plastic bag, and duct tape. Whereas the tools used were the Global Positioning System (GPS), camera, stationary, ruler, as well as orchid's manual identification book.

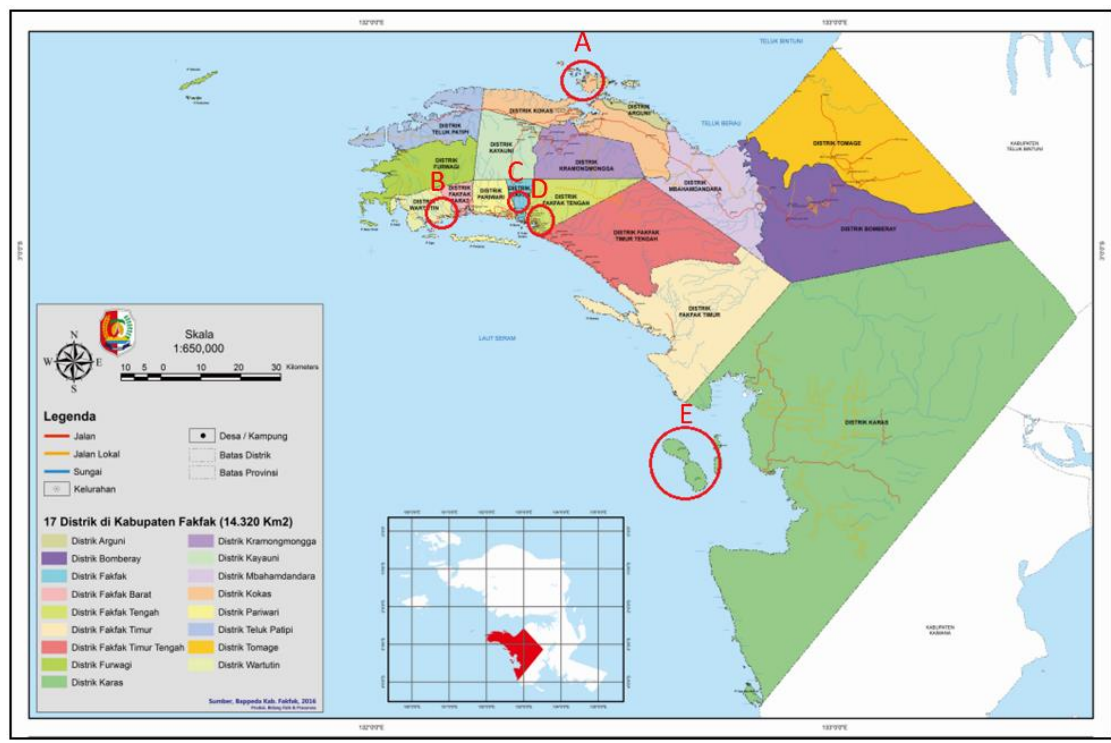

Figure 1. Five study locations: (A) Ugar Village Forest, Kokas District; (B) Hanatpona Forest, Wartutin District; (C) Fakfak Mountain Nature Reserve, Fakfak District; (D) Air Besar Forest and Sekartemen Forest, Fakfak Tengah District; (E) Maas Village Forest, Karas District). (Source: Badan Pusat Statistik Kabupaten Fakfak, 2014) 


\subsection{Research Method}

Sampling was carried out using the Visual Encounter Survey (VES) and the purposive exploration method (Saputra, Tibalia, Darwis, \& Sumirto, 2018). Only orchid plants that are flowering or showing the key characters were recorded. Data were recorded by taking the photographs of orchids lifeforms, leaves, inflorescences, as well as the coordinate location at every spot where orchids were identified during the survey. Furthermore, the living collection was taken by using rice sacks for epiphytic orchids, and using their substrate within the plastic bag for terrestrial and holomycotrophic orchids. Soon after arrived at temporary camp, the orchid specimens were preserved using $70 \%$ alcohol for further identification purposes. Treatment for terrestrial orchids were carried out using Kadaka medium (Asplenium nidus L.) and soil medium. Living collection for holomycotrophic orchids did not executed prior to their short life cycle (die quickly). The specimens were then identified using the book "Orchids of Papua New Guinea" (Millar, 1999), "Lowland Orchids of Papua New Guinea" (O’Byrne, 1994), and "A Guide to Dendrobium of New Guinea" (Schuiteman, 2013), as well as assistance from the Orchids Experts in LIPI, RBG Kew, and Hortus Botanicus Leiden.

\subsection{Data Analysis}

Raw data during orchids collection consists of the scientific name and GPS location followed by re-checking for their latest scientific name at POWO Kew (powo.kew.org), global conservation status (iucnredlist.org), global trading status (checklist.cites.org), and their protection status by Ministry of Environment and Forestry Decree (SK KLHK No. P.106, 2018). Data on diversity and distribution of orchids were categorized and analyzed by Microsoft Excel (Microsoft.inc, USA).

\section{Results and Discussion}

\subsection{Orchids diversity study}

This study identified 67 species belonging to 33 genera, consisting of 49 epiphytic orchid, 16 terrestrial, and two holomycotrophic orchids (Table 1). Identification process until species level was not always successful even though the collected specimens only taken to those of flowered ones. Thus, for several specimens, the identification just can be carried out until the genus or section level. Some specimens are undescribed and some are under preparation for proposing as new species. Identification result for orchids specimens are shown in Figure 2.

The result of this study showed higher value than that of predicted orchids richness in Fakfak Regency, viz. 30-50 orchids species (Vollering et al., 2016). Limited specimens' collection by previous works (Vollering et al., 2016) may be the factor that being the cause for the differences in species richness. The result of previous research was also only a prediction orchids model that could be somewhat biased if applied in different location. Nevertheless, this current study is based on direct exploration in the field and may deliver more reliable data.

Other orchids exploration also had conducted in the Bird's Head Peninsula, specifically in the Sorong City forest with a result of 84 orchids species (Saputra, Tibalia, et al., 2018). Higher orchids diversity was found compare to the present work. The lower diversity recorded in this present work may be attributed to the limited resources and fewer surveyed pristine forest, especially at Fakfak Nature Reserve that may still contains hundreds of uncovered species. In both location Sorong and Fakfak, there were also similar recorded species, i.e

Dendrobium

Grammatophyllum capituliflorum, Spathoglottis papuana, etc. Those common species are widespread in the Papua lowland rainforest. The highland orchids are absent in Sorong site, for 
instance, Goodyera lamprotaenia and $G$. stenopetala. Considering the possibility of high diversity orchid, it was possible that there would be more than 150 species of orchids growing naturally in Fakfak Regency.

The most diverse genus is Dendrobium orchids with 18 different species, followed by Bulbophyllum with six species and Taeniophyllum with five different species. It is quite related to
Camara-Leret et al. (2020) research that shows Bulbophyllum and Dendrobium as the two largest genera in New Guinea. Currently, there are about 658 species of Bulbophyllum, and 614 species of Dendrobium growing in New Guinea (Cámara-Leret et al., 2020; Saputra et al., 2020). Furthermore, Taeniophyllum has its main area of diversity in New Guinea with approximately 90 species.

Table 1. Orchids diversity and distribution in five districts in Fakfak Regency, West Papua

\begin{tabular}{|c|c|c|c|c|c|c|c|c|c|c|}
\hline No & Species Name & FT & FF & KK & $\mathbf{K R}$ & WR & IUCN & CITES & P.106 & Lifeform \\
\hline 1 & Acriopsis javanica Reinw. ex Blume & + & & & & & $\mathrm{NE}$ & II & $x$ & \\
\hline 2 & Appendicula reflexa Blume. & + & & & & & $\mathrm{NE}$ & II & $x$ & \\
\hline 3 & Brachypeza indusiata (Rchb.f.) Garay & + & + & + & + & + & $\mathrm{NE}$ & II & $x$ & \\
\hline 4 & Bryobium erioides M.A.Clem. \& D.L.Jone & & + & & & & $\mathrm{NE}$ & II & $x$ & \\
\hline 5 & Bulbophyllum clandestinum Lindl. & & + & & & & $\mathrm{NE}$ & II & $x$ & \\
\hline 6 & Bulbophyllum infundibuliforme J.J.Sm. & + & & & & & $\mathrm{NE}$ & II & $x$ & \\
\hline 7 & Bulbophyllum lepanthiflorum Schltr. & & + & & & & NE & II & $x$ & \\
\hline 8 & Bulbophyllum sp. Sect. Beccariana & + & & & & & $\mathrm{NE}$ & II & $x$ & \\
\hline 9 & Bulbophyllum sp. Sect. Codonosiphon & + & & & & & $\mathrm{NE}$ & II & $x$ & \\
\hline 10 & Bulbophyllum stabile J.J.Sm. & & + & & & & DD & II & $x$ & \\
\hline 11 & Ceratostylis subulata Blume. & & + & & & & $\mathrm{NE}$ & II & $x$ & \\
\hline 12 & Cleisostoma firmulum Rchb.f. & & + & & & & $\mathrm{NE}$ & II & $x$ & \\
\hline 13 & Coelogyne asperata Lindl. & + & + & & & & $\mathrm{NE}$ & II & $x$ & \\
\hline 14 & Coelogyne beccarii Rchb.f. & + & + & & & & $\mathrm{NE}$ & II & $x$ & \\
\hline 15 & Dendrobium antennatum Lindl. & & & + & & + & $\mathrm{NE}$ & II & $x$ & \\
\hline 16 & Dendrobium bracteosum Rchb.f. & & & + & & & $\mathrm{NE}$ & II & $x$ & \\
\hline 17 & Dendrobium angraecifolium Schltr. & + & & & & & $\mathrm{NE}$ & II & $x$ & Epiphytic \\
\hline 18 & Dendrobium capituliflorum Rolfe. & + & & & & & $\mathrm{NE}$ & II & $x$ & \\
\hline 19 & Dendrobium cochliodes Schltr. & + & & & & & $\mathrm{NE}$ & II & $x$ & \\
\hline 20 & Dendrobium funiforme Blume. & & & + & + & & $\mathrm{NE}$ & II & $\times$ & \\
\hline 21 & Dendrobium hosei Ridl. & + & & & & & $\mathrm{NE}$ & II & $x$ & \\
\hline 22 & Dendrobium insigne Rchb.f. ex Miq. & + & & & & & $\mathrm{NE}$ & II & $x$ & \\
\hline 23 & Dendrobium mirbelianum Gaudich. & & & & + & & NE & II & $x$ & \\
\hline 24 & Dendrobium piestocaulon Schltr. & + & & & & & $\mathrm{NE}$ & II & $x$ & \\
\hline 25 & Dendrobium poneroides Schltr. & + & & & & & $\mathrm{LC}$ & II & $x$ & \\
\hline 26 & Dendrobium roseipes Schltr. & + & & & & & $\mathrm{NE}$ & II & $x$ & \\
\hline 27 & Dendrobium pseudocalceolum J.J.Sm & & & & + & & $\mathrm{NE}$ & II & $x$ & \\
\hline 28 & Dendrobium smillieae F. Muell. & & + & & & & $\mathrm{NE}$ & II & $x$ & \\
\hline 29 & Dendrobium sp. Sect. Diplocaulobium & & + & & & & $\mathrm{NE}$ & II & $x$ & \\
\hline 30 & Dendrobium sp. Sect. Grastidium & + & & & & & $\mathrm{NE}$ & II & $x$ & \\
\hline 31 & Dendrobium sp. Sect. Flickingeria & + & & & & & $\mathrm{NE}$ & II & $x$ & \\
\hline 32 & $\begin{array}{l}\text { Dendrobium taylorii (F.Muell.) } \\
\text { F.M.Bailey }\end{array}$ & + & & + & + & & $\mathrm{NE}$ & II & $x$ & \\
\hline
\end{tabular}




\begin{tabular}{|c|c|c|c|c|c|c|c|c|c|c|}
\hline No & Species Name & FT & FF & KK & KR & WR & IUCN & CITES & P.106 & Lifeform \\
\hline 33 & Grammatophyllum speciosum Blume & + & & & & & $\mathrm{NE}$ & II & $x$ & \\
\hline 34 & Grammatophyllum scriptum (L) Blume & + & + & & & & NE & II & $x$ & \\
\hline 35 & Oberonia cuneata J.J.Sm. & & + & & & & $\mathrm{NE}$ & II & $x$ & \\
\hline 36 & Oberonia phleoides Schltr. & + & & & & & $\mathrm{NE}$ & II & $x$ & \\
\hline 37 & $\begin{array}{l}\text { Oxystophyllum torricellianum } \\
\text { M.A.Clem. }\end{array}$ & + & & & & & NE & II & $x$ & \\
\hline 38 & \multicolumn{2}{|l|}{ Dryadorchis singularis Christenson \& Schuit. } & & + & & & $\mathrm{NE}$ & II & $x$ & \\
\hline 39 & Phreatia aff. brachystachys Schltr. & & & + & & & NE & II & $x$ & \\
\hline 40 & Podochilus scalpelliformis Blume. & & & + & & & NE & II & $x$ & \\
\hline 41 & $\begin{array}{l}\text { Schoenorchis micrantha Reinw. ex } \\
\text { Blume }\end{array}$ & + & & & & & NE & II & $x$ & \\
\hline 42 & Stichorkis gibbosa (Finet) J.J.Wood. & & + & & & & NE & II & $x$ & \\
\hline 43 & Taeniophyllum sp. Sect. Loboglossum & + & & & & & NE & II & $x$ & \\
\hline 44 & Taeniophyllum apiculatum J.J.Sm & + & & & & & $\mathrm{NE}$ & II & $x$ & \\
\hline 45 & Taeniophyllum arachnites J.J.Sm & + & & & & & NE & II & $x$ & \\
\hline 46 & Taeniophyllum cf. aureum Schltr. & + & & & & & $\mathrm{NE}$ & II & $x$ & \\
\hline 47 & Taeniophyllum cf. xerophilum Schltr. & + & & & & & $\mathrm{NE}$ & II & $x$ & \\
\hline 48 & Thelasis carinata Blume. & + & & & & & NE & II & $x$ & \\
\hline 49 & Thelasis mamberamensis J.J.Sm. & & + & & + & & $\mathrm{NE}$ & II & $x$ & \\
\hline 50 & Thelasis micrantha (Brongn.) J.J.Sm. & + & & & & & NE & II & $x$ & \\
\hline 51 & Trichoglottis papuana Schltr. & + & & & & & NE & II & $x$ & \\
\hline 52 & Didymoplexiella sp. & & + & & & & $\mathrm{NE}$ & II & $x$ & Holo- \\
\hline 53 & Epipogium roseum (D.Don) Lindl. & & + & & & & $\mathrm{NE}$ & II & $x$ & $\begin{array}{l}\text { myco- } \\
\text { trophic }\end{array}$ \\
\hline 54 & Corymborkis veratrifolia (Reinw.) Blume. & & + & & & & NE & II & $x$ & \\
\hline 55 & Eria javanica (Sw.) Blume. & & & + & & & NE & II & $x$ & \\
\hline 56 & Erythrodes papuana Schltr. & & + & & & & NE & II & $x$ & \\
\hline 57 & Erythrodes bicarinata Schltr. & & + & & & & NE & II & $x$ & \\
\hline 58 & Eulophia pulchra (Thouars) Lindl. & + & & & & & $\mathrm{NE}$ & II & $x$ & \\
\hline 59 & Goodyera rubicunda (Blume) Lindl. & & + & & & & $\mathrm{NE}$ & II & $x$ & \\
\hline 60 & Goodyera aff. lamprotaenia Schltr. & & + & & & & $\mathrm{NE}$ & II & $x$ & trial \\
\hline 61 & Goodyera aff. stenopetala Schltr. & & + & & & & $\mathrm{NE}$ & II & $x$ & \\
\hline 62 & Macodes sanderiana (Kraenzl.) Rolfe. & + & & & & & NE & II & $x$ & \\
\hline 63 & Nervilia aragoana Gaudich. & + & + & & & + & NE & II & $x$ & \\
\hline 64 & Paphiopedilum glanduliferum Stein. & & & & + & & EN & I & $\checkmark$ & \\
\hline 65 & Plocoglottis moluccana Blume. & & + & & & & $\mathrm{NE}$ & II & $x$ & \\
\hline 66 & Spathoglottis papuana F.M.Bailey & + & + & + & + & + & NE & II & $x$ & \\
\hline 67 & Tropidia disticha Schltr. & + & & & & + & NE & II & $x$ & \\
\hline & TOTAL & 37 & 26 & 10 & 8 & 5 & & & & \\
\hline
\end{tabular}

Remarks: IUCN=NE: Not Evaluated, EN:Endangered; CITES=I:Appendix I, II:Appendix II; Protected by Indonesian Government $=x:$ no, $\checkmark$ : yes.

Epiphytic is a form of plant relationship when one plant grow on another living plant (Darma, Setyo Lestari, Priyadi, \& Iryadi, 2018) without being parasitic (Mondragón, Valverde, \& Hernández-Apolinar, 2015). One example of an epiphytic orchid is Dendrobium bracteosum Rchb.f. that having four different color of flower (red, purple, pink, and white) with yellowish orange or rarely purplish red of lip. This orchid can be found in lowland forests, usually in shaded spots from 0 to $800 \mathrm{~m}$ asl (Saputra, et al., 2018). This orchids flowers 
throughout the year and lasts for four months (O’ Byrne, 1994). Their attractive bright color and long-lasting flower have made $D$. bracteosum to be potential as a high-value ornamental plant.

An example of terrestrial orchids, Nervilia aragoana Gaudich, has a heart-shaped like leaves and separate from the generative phase (flowers). $N$. aragoana is a very widespread species that bears 4-16 flowers, green petals and a white lip that is marked with dark green or brownish-purple lines and which bears tall, white hairs primarily along the main veins on the disk (Gale et al., 2016). Field observation determined that generative and vegetative phase are located closely. The leaves only emerge after the inflorescence has faded. $N$. aragoana has green leaves and yellowish green flowers that indicate chlorophyll's presence, thus enabling the organs to carry out photosynthesis and store their photosynthetic products in their tuber. The tuber organ of $N$. aragoana was reported as a traditional medicine for epilepsy, asthma (Pant, 2013), and diuretic problem (Thomas, Aneesh, Thomas, \& Anandan, 2013), as well as to increase stamina and aphrodisiac (Silalahi, Nisyawati, Walujo, Supriatna, \& Mangunwardoyo, 2015). Moderate light intensity and humidity are preferable habitat for $N$. arogana growing in the Fakfak Mountains Nature Reserve, Air Besar Forest, and Hanatpona Forest.

One example of a holomycotrophic orchid is Epipogium roseum (D.Don) Lindl. which only has roots, stems, and flowers. Their pale stem and flower are among their morphological camouflage to blend with their surrounding that make them rather difficult to recognize. The genus Epipogium Borkh. is a group of orchids included in holomycotrophic plants. Holomycotrophic is a symbiotic plant that growing on dead and decaying matter, and the entire life cycle is completely dependent on mycorrhizae (Jalal \& Jayanthi, 2012). E. roseum was found growing on the moist forest floor with low light intensity in the Fakfak Mountains Nature Reserve, which has a lot of leaf litter with high humidity and low light intensity.

Based on the concervation status, several orchids were in Appendix I (CITES), Endangered (IUCN), and protected by the Government of Indonesia regulation, i.e. Paphiopedilum glanduliferum (Blume) Stein. This orchid belongs to a group of slipper orchids (anggrek kantung) that is in great demand by orchid lovers worldwide. Therefore, every year, the population of $P$. glanduliferum in the nature is decreasing due to many factors such as deforestation, ruthless exploitation, and soil erosion (Rankou \& Sullivan, 2015).

\subsection{Distribution Pattern}

Fakfak Tengah District had the most significant number of orchids compare to other four districts, i.e. 37 species (Table 1). Fakfak District as known for its highland area are supposedly to have richer orchid than those in other lowland districts. The higher number of species found in Fakfak District may also generated from the surveyed forest that covered two observation areas, i.e. the Sekartemen Forest and Air Besar Forest. Moreover, Fakfak Tengah District has the most observation frequency among others.

This study only covers a small area of whole Fakfak Mountains Nature Reserves in Fakfak District (elevation 250-1,000 $\mathrm{m}$ asl), however, this less extensive study still resulted in high number of orchids found within the area. Vollering et al. (2016) predicted the orchids diversity pattern where higher elevation will show higher predicted richness. However, their research shows that New Guinean orchid richness is maximized within a montane elevational band ranging from approximately 2,000 to $3,000 \mathrm{~m}$ and decreasing as altitude increases. 


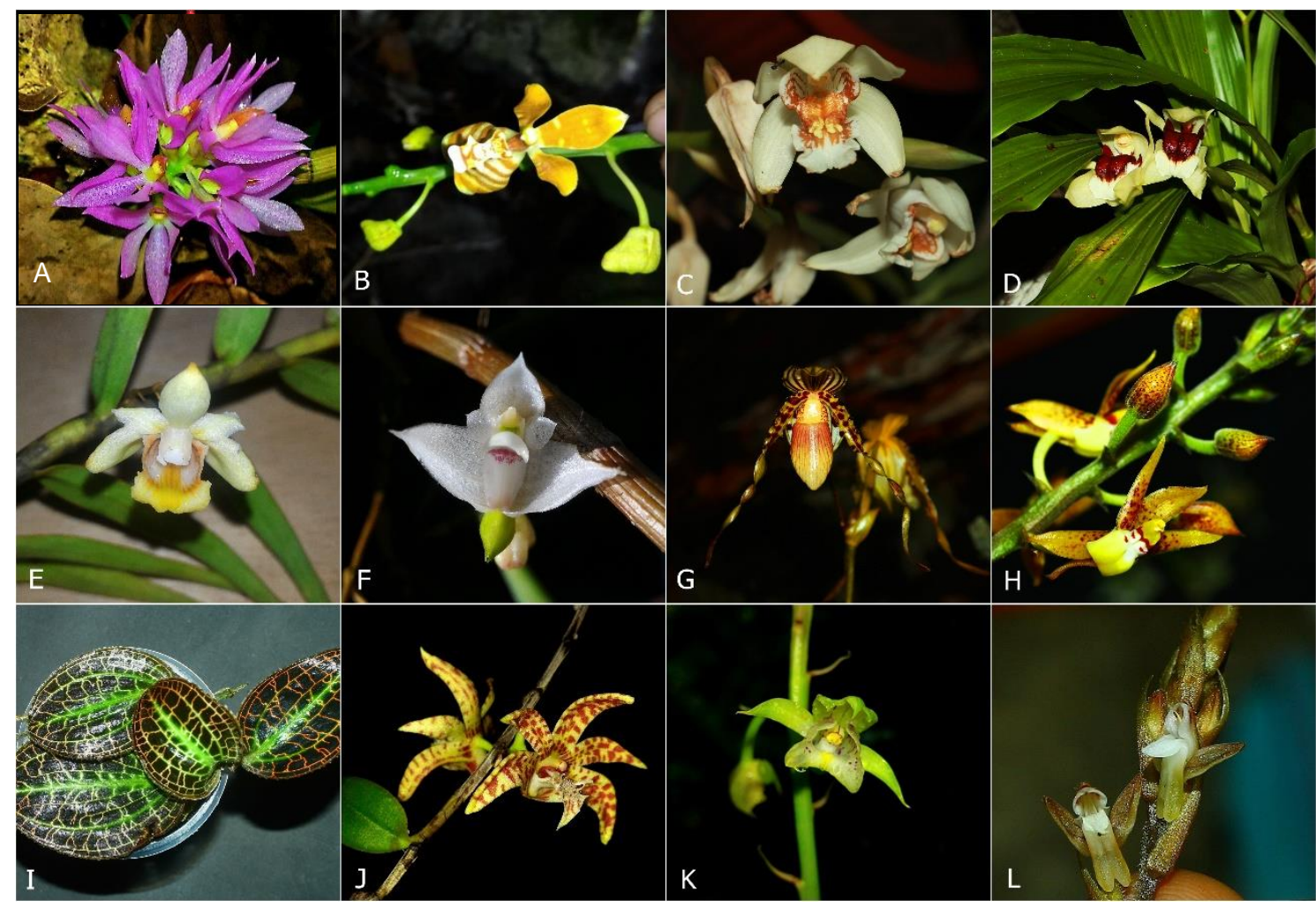

Figure 2. Some of the orchids found in Fakfak Regency. A. Dendorbium bracteosum, B. Dryadorchis singularis, C. Coelogyne asperata, D. Coelogyne beccarii, E. Dendrobium hosei, F. Dendrobium piestocaulon, G. Paphiopedillum glanduliferum, H. Plocoglottis moluccana, I. Macodes sanderiana, J. Dendrobium insigne, K. Eulophia pulchra, L. Erythrodes papuana.

Fakfak Mountain Nature Reserve is a huge landscape that provide supported habitat for all orchids lifeforms, i.e. epiphytic, holomycotrophic, and terrestrial. From all recorded lifeforms, the most interesting is the presence of holomycotrophic orchids. It only appears in the Fakfak Mountain Nature Reserve, Fakfak District, above $500 \mathrm{~m}$ asl. Holomycotrophic is a group of plants that entirely depends on mycorrhizae fungi in the soil. Because of its high relation to mycorrhizae, any changes in the soil could threaten their survival. Orchid is commonly known to be a bio-indicator and early warning system of the natural forest. Their presence reveals that the forest is in decent condition. Their absence will give an early warning of the forest health and condition (Swarts \& Dixon, 2009).
Even though the Fakfak Mountains Nature Reserve in Fakfak District hold the second place for its orchid's diversity, it still keeps many various species of orchids. Most of them only found in that 1,300 m asl mountain. Based on Agustini, Zebua, \& Wenda (2016), some of the Papuan orchids can only be seen in high montane forest above $1,200 \mathrm{~m}$ asl. For instance, Dendrobium spiculatum Schuit. The species is endemic to Arfak Mountain in altitude about 2,100 $\mathrm{m}$ asl (Schuiteman \& Wanma, 2017). Higher altitudes is beneficial for its less anthropogenic disturbance, furthermore nature reserve status also plays a huge role in preserving biodiversity (Takandjandji \& Kwatrina, 2011), and it influences the diversity of orchids. This current study can be determined as an initial step for further and deeper study of the orchid richness within this biodiversity spots. 
There are most common orchids species found in all districts, viz. Spathoglottis papuana Schltr. S. papuana is a native orchid species that widely growing in New Guinea. Their widespread characteristic may attributed to its tolerance for various environmental types, especially in open habitat (Saputra, Farishy, \& Suratman, 2018). The author found the most abundant $S$. papuana population in the open habitat of the national road (Fakfak-Kokas) through the Fakfak Mountain Nature Reserve.

\section{Conclusion}

Research on orchids growing in Fakfak regency has been less studied. Current study determined 67 collection numbers consisting of 49 epiphytic orchids, 16 terrestrial orchids, and two holomycotrophic orchids belonging to 33 genera and 67 species. Fakfak Tengah District has the highest number of orchid collection with 37 orchids.

\section{Acknowledgment}

The author would like to thanks the NKRI Expedition 2016: West Papua Corridor, which has facilitated this research. Inggit Puji Astuti, as the Chairperson of the Flora Fauna Team Expert. Destario Metusala, Lina Juswara, André Schuiteman, and Eduard de Vogel which has helped the identification process.

\section{References}

Agustini, V., Zebua, L. I., \& Wenda, N. (2016). Inventory of native orchids in Makki Sub-District, Lanny Jaya, Papua, Indonesia. Biodiversitas, 17(1), 301-305. https://doi.org/10. 13057/biodiv/d170141

Badan Pusat Statistik Kabupaten Fakfak. (2014). Kabupaten Fakfak dalam Angka 2014. Kabupaten Fakfak: Badan Pusat Statistik Kabupaten Fakfak.
Cámara-Leret, R., Frodin, D. G., Adema, F., Anderson, C., Appelhans, M. S., Argent, G., ... van Welzen, P. C. (2020). New Guinea has the world's richest island flora. Nature, 584(7822), 579-583. https://doi.org/ 10.1038/s41586-020-2549-5

Darma, I. D. P., Setyo Lestari, W., Priyadi, A., \& Iryadi, R. (2018). Paku epifit dan pohon inangnya di Bukit Pengelengan, Tapak dan Lesung, Bedugul, Bali. Jurnal Penelitian Hutan Dan Konservasi Alam, 15(1). https://doi.org/10.20886/jphka.2018. 15.1.41-50

Gale, S. W., Schuiteman, A., Watthana, S., Sando, T., Souvannakhoummane, K., Averyanov, L., \& Suddee, S. (2016). Studies in asian nervilia (Nervilieae, epidendroideae, orchidaceae) VI: N. mekongensis, a new species from Thailand, Cambodia, Laos and Vietnam. Phytotaxa, 247(4), 267-273. https://doi.org/ 10.11646/phytotaxa.247.4.4

Jalal, J. S., \& Jayanthi, J. (2012). Endemic orchids of peninsular India: a review. Journal of Threatened Taxa, 4(15), 3415-3425. https://doi.org/10.11609/ jott.o3091.3415-25

Juswara, L., Schuiteman, A., \& Droissart, V. (2016). Four new orchid species from the Lengguru fold belt, West Papua, Indonesia. PhytoKeys, 61(1), 47-59. https://doi.org/10.3897/ phytokeys.61.7590

Mondragón, D., Valverde, T., \& Hernández-Apolinar, M. (2015). Population ecology of epiphytic angiosperms: A review. Tropical Ecology, 56(1), 1-39. https://doi.org/ 10.13140/2.1.4043.5849 
O’ Byrne, P. (1994). Lowland Orchids of Papua New Guinea. Singapore: SNP Publisher Pte Ltd.

Pant, B. (2013). Medicinal orchids and their uses: Tissue culture a potential alternative for conservation. African Journal of Plant Science, 7(10), 448467. https://doi.org/10.5897/ ajps2013.1031

Pemerintah Kabupaten Fakfak. (2011). Rencana Tata Ruang Wilayah (RTRW) Kabupaten Fakfak 20112031. Kabupaten Fakfak: Bappeda Kabupaten Fakfak.

Rankou, A., \& Sullivan, O. (2015). Paphiopedilum glanduliferum. The IUCN Red List of Threatened Species. https://doi.org/10.2305/IUCN.UK.20 15-2.RLTS.T43320333A43327839. en

Saputra, R., Farishy, D. D. Al, \& Suratman, D. (2018). Orchids of Sorong Nature Recreation Park (D. Metusala, W. A. Mustaqim, \& T. Haryanto, eds.). Sorong: Balai Besar KSDA Papua Barat.

Saputra, R., Tibalia, D., Darwis, F., \& Sumirto, A. (2018). Keanekaragaman Anggrek (Orchidaceae) di Taman Wisata Alam Sorong, Kota Sorong, Papua Barat. Jurnal Biologi Papua, 10(2), 74-79. https://doi.org/10. $31957 / j b p .492$

Saputra, R., Mustaqim, W. A., Metusala, D., \& Schuiteman, A. (2020). Dendrobium sagin (Orchidaceae: Epidendroideae), a new species from the Bird's Head Peninsula, West New Guinea. Phytotaxa, 459(2), 190-196. https://doi.org/10.11646/phytotaxa.4 59.2 .9

Schuiteman, A., \& Wanma, J. F. (2017). New and Noteworthy Orchid Species from the Arfak Mountains, West
Papua Province, Indonesia. Malesian Orchid Journal, 20(August), 75-90.

Silalahi, M., Nisyawati, Walujo, E. B., Supriatna, J., \& Mangunwardoyo, W. (2015). The local knowledge of medicinal plants trader and diversity of medicinal plants in the Kabanjahe traditional market, North Sumatra, Indonesia. Journal of Ethnopharmacology, 175, 432-443. https://doi.org/10.1016/j.jep.2015.09. 009

Surat Keputusan Menteri Lingkungan Hidup dan Kehutanan (2018). Perubahan kedua atas peraturan Menteri Lingkungan Hidup dan Kehutanan Nomor P.20/Menlhk/ Setjen/Kum.1/6/2018 tentang jenis tumbuhan dan satwa yang dilindungi (SK KLHK No. P.106/MENLHK/SETJEN/KUM.1/1 2/2018).

Swarts, N. D., \& Dixon, K. W. (2009). Terrestrial orchid conservation in the age of extinction. Annals of Botany, 104(3), 543-556. https://doi.org/10. 1093/aob/mcp025

Takandjandji, M., \& Kwatrina, R. T. (2011). Pengelolaan Cagar Alam Pulau Dua di Provinsi Banten sebagai ekosistem bernilai penting. Jurnal Penelitian Hutan dan Konservasi Alam, 8(1), 95-108. https://doi.org/10.20886/jphka.2011. 8.1.95-108

Thomas, E., Aneesh, T. P., Thomas, D. G., \& Anandan, R. (2013). GC-MS analysis of phytochemical compounds present in the rhizomes of Nervilia aragoana GAUD. Asian Journal of Pharmaceutical and Clinical Research, 6(SUPPL.3), 6874.

Vollering, J., Schuiteman, A., de Vogel, E., van Vugt, R., \& Raes, N. (2016). 
Phytogeography of New Guinean orchids: Patterns of species richness and turnover. Journal of
Biogeography, 43(1), 204-214. https://doi.org/10.1111/jbi.12612 